\title{
Research Involvement of Pharmacy Faculties in India
}

\author{
Prasanna R Deshpande ${ }^{1,2}$, Vikas R. Chandrakar ${ }^{3}$, Kiran Bhusare ${ }^{4}$, Tarachand Lalwani ${ }^{5}$, \\ M Naga Lakshmi Prasanna ${ }^{6}$, Ashish Kanhed ${ }^{7}$, Atmaram P Pawar ${ }^{7}$
}

\author{
${ }^{1}$ Department of Clinical Pharmacy, Poona College of Pharmacy, Bharati Vidyapeeth, Pune, Maharashtra, INDIA. \\ ${ }^{2}$ Chalapathi Institute of Pharmaceutical Sciences, Guntur, Andhra Pradesh, INDIA. \\ ${ }^{3}$ Department of Pharmacy, Sumandeep Vidyapeeth, Baroda, Gujarat, INDIA. \\ ${ }^{4}$ Bhagwan College of Pharmacy, Aurangabad, Maharashtra, INDIA. \\ ${ }^{5}$ Pharmacy Department, Rajdhani Super Speciality Hospital, Raipur, Chattisgarh, INDIA. \\ ${ }^{6}$ Vijaya institute of Pharmaceuticals for Women, Enekepadu, Vijayawada, INDIA. \\ ${ }^{7}$ Poona College of Pharmacy, Bharati Vidyapeeth, Pune, Maharashtra, INDIA.
}

\begin{abstract}
Objective: The contribution of Indian pharmacy research is unremarkable in the world. Hence, we aimed to determine the research involvement and research productivity of Indian pharmacy faculties. Methods: A questionnaire evaluating research involvement and research productivity of the faculties was developed, validated and sent to 7536 email addresses. The main question categories in the questionnaire were- demographics, journal related research activities, conference related research activities, opinions about research and others. Results: We received 295 responses with the response rate of $3.91 \%$. The male: female ratio was 2.78 . The important average values in the survey were- experience in teaching $/$ research $=12.51$ years, Time spent on research/related activities $=131.56 \mathrm{~min} /$ day, Research based publications $=34.3$, Patents received $=0.90$. Conclusion: Although our study generates huge 'quantitative' data, serious inputs are needed to improve the overall 'quality' of Indian pharmacy academic research. Further research is indeed required to strengthen the field.
\end{abstract}

Key words: Pharmacy Education, India, Pharmacy, Faculty research, Academic research, Research involvement.

\section{INTRODUCTION}

India has a variety of pharmacy programs and also has numerous pharmacy institutes. As far as job distribution after pharmacy career in India is considered, according to Global Pharmacy Workforce and Migration report ${ }^{1}$ currently there are $55 \%$ community pharmacists, $20 \%$ hospital pharmacists, $10 \%$ industrial/regulatory pharmacists and only $2 \%$ academic pharmacists. The major areas for academicians to work are teaching, academic/community services, practice, administration and research. Research contribution is one of the major factors determining the credibility of a faculty member.

Research plays an important role in development of a field and eventually the nation. According to the website of Pharmacy Council of India (PCI), there are total
2767 pharmacy institutes exist in India offering different pharmacy courses; the distribution is as follows- approved and 'only for conduct' diploma institutes- $840^{2}$, 3 approved and 'only for conduct' degree institutes- $1140^{4,5}$ approved PharmD institutes-2246 approved institutes for bridge course- $17^{7}$ and approved institutes for M. Pharm-546. ${ }^{8}$ But despite of India having numerous pharmacy institutes, the nation's research contribution in the world is not that significant and it's a matter of concern. Looking at the evidences, India ranks at $60^{\text {th }}$ position in the world in terms innovations, according to Global Innovation Index (GII) 2017; many geographically smaller countries are ahead than us. ${ }^{9}$ Furthermore, the contribution of India in pharmaceutical sciences
Submission Date: 01-07-2017; Revision Date: 25-09-2017; Accepted Date: 10-01-2018

DOI: 10.5530/ijper.52.1.3 Correspondence: Dr. Prasanna R Deshpande, Department of Clinical Pharmacy, Poona College of Pharmacy, Bharati Vidyapeeth University, Pune, Maharashtra, INDIA.

Phone no: +91-2025461046 E-mail: prasanna.deshpande17@gmail.com

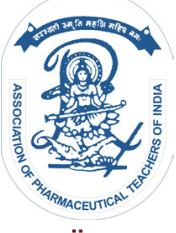

www.ijper.org 
is also not very significant in the world; the details are as follows- global author share- $5.66 \%$, global journal share- $0.80 \%$, total impact factor of the journals- 2.68 etc. ${ }^{10}$

To know the exact status of research involvement of pharmacy faculties in India, we could not observe any previous survey/official information in the literature. Although PCI has recently started maintaining a database of research publications by pharmacy institutes. ${ }^{11}$ it doesn't give the complete research profile/information of a faculty, such as number of patents, member of editorial board, reviewer of journal/s, number of podium/poster presentations, research grants received and many such factors. To the best of our knowledge, there is no survey conducted for Indian pharmacy academicians assessing their research involvement and productivity. Therefore, we aimed to determine the same.

\section{OBJECTIVES}

To analyze the research involvement and research productivity of pharmacy faculties in India by using different parameters

To determine average values for the parameters assessing research productivity of the faculties

\section{METHODS}

The approval was obtained to conduct the study from institutional review committee.

\section{Study design}

This was a web-based survey of current Indian pharmacy academicians to analyze their research involvement. Pharmacy academicians currently enrolled in any Indian institute were considered to be eligible for the survey.

\section{The instrument}

\section{Development of the instrument}

A draft survey instrument was framed by considering the following aspects- curriculum vitae of faculties, and faculty interviews.

Curriculum vitae of 8 senior faculties of different reputed pharmacy institutes in India were overviewed (from the institute's website) to know the general research activities conducted by a faculty. Seven faculties from different specializations were interviewed to determine the possible parameters for a pharmacy academician to assess his research contribution.

\section{Validation of the instrument}

Validation of the instrument was conducted by expert review and pilot study. Four experts were consulted to opine about the survey instrument. They were asked to comment on content, flow, grammar, simplicity, reliability, and importance of the questionnaire. Their comments were used to improve the instrument. Then, the instrument was administered to 5 faculties on pilot basis. The amendments made by them were also considered for finalizing the questionnaire. The responses obtained from pilot study were not considered during final calculations of the survey.

\section{The questionnaire details}

After development and validation, the instrument with 40 items was finalized. The questionnaire details were as shown in Table 1.

\section{Sending the survey instrument}

This web-based survey was conducted by using "Google forms". The survey instrument was sent to pharmacy academicians in different institutes in India by following means- through head of the institutes/departments, personal contacts (primary, secondary and tertiary), through email addresses of faculties on the institutes' organization's website, NGOs/associations of pharmacy teachers, Facebook groups etc. All the current faculties in Indian pharmacy institutes were considered to be eligible for the survey. Informed consents were obtained from the faculties. It was mandatory to answer each question in the survey. Identity of every respondent was maintained anonymous and confidential.

\section{Outcome and data analysis}

The online version of the survey questionnaire was available for accepting the responses for 15 months. Microsoft excel was used for the data analysis. Convenience and snowball samplings were adopted. Cronbach alpha of the questionnaire was calculated by using the online calculator. ${ }^{12}$ Raosoft calculator was used to calculate margin of error. ${ }^{13}$

\section{How were the average values determined?}

To determine the average values related to research productivity, we first determined the median (m) for a range of an option. Then, we multiplied the median by the number of responses (n). Afterwards, the total value was determined by summing the ' $\mathrm{n} X \mathrm{~m}$ ' values for each option. The total value was then divided by total number of responses i.e. 295 to determine the average value for the question.

e.g. (Table 3) to calculate average research-based publications by a faculty, the median value of the option '1-10' was calculated first i.e. 5.5. Then the median was multiplied by the number of responses (i.e. 108) to determine the total publications for this option 


\begin{tabular}{|c|c|c|c|}
\hline $\begin{array}{l}\text { Sr. } \\
\text { No. }\end{array}$ & Question category & Question about & $\begin{array}{c}\text { No. of } \\
\text { questions }\end{array}$ \\
\hline 1 & Demographics of the faculty & $\begin{array}{c}\text { Designation, Gender, Set up of the institute, Highest qualification, } \\
\text { Location of the institute, Type of students teaching/administering, } \\
\text { Total experience, Area of interest for research, Type of research } \\
\text { involved in etc. }\end{array}$ & 09 \\
\hline 2 & $\begin{array}{l}\text { Research conducted in the past/ } \\
\text { until now (related to journals) }\end{array}$ & $\begin{array}{l}\text { Number of research publications (as the first author and as a } \\
\text { coauthor), Editorial board member (Number of journals), Worked as a } \\
\text { reviewer (number of journals and number of manuscripts) etc. }\end{array}$ & 05 \\
\hline 3 & $\begin{array}{l}\text { Research conducted in the } \\
\text { past/until now (related to } \\
\text { conferences) }\end{array}$ & $\begin{array}{l}\text { Total number of conferences attended, Total podium presentations, } \\
\text { Total poster/paper presentations (as the first and the co-author), } \\
\text { Abstract publications, Abstract reviewer in number of conference/s, } \\
\text { Podium/poster evaluator, Non-scientific committee work }\end{array}$ & 08 \\
\hline 4 & Miscellaneous & $\begin{array}{l}\text { Patents received, Total research grant received, Number of research } \\
\text { publications indexed with PubMed/Medline, Number of best paper/ } \\
\text { presentation/publication awards received, Number of students guided } \\
\text { for research (UG, PG, PharmD and PhD), Status of membership of } \\
\text { research committee of the institute, Average time spent for research } \\
\text { every day, Number of ongoing projects, h-index, i-10 index, total } \\
\text { number of citations etc. }\end{array}$ & 14 \\
\hline 5 & Opinions & $\begin{array}{l}\text { Reasons for less research, Recommendation/s for improving the } \\
\text { research, Recommendation/s to improve students' involvement in } \\
\text { research, Any other comments }\end{array}$ & 04 \\
\hline Total & & & 40 \\
\hline
\end{tabular}

$(5.5$ X $108=594)$. Likewise, all values were determined for each option to get total value of 10,119. In the end, 10, 119 was divided by total number of responses (295) to get average value of 34.30 .

\section{RESULTS}

Total of 7536 email addresses were obtained from websites of 108 pharmacy institutes, 01 association, and personal contacts. Out of 7536, 295 faculties responded to the survey. The proportion of bounce emails was $8.2 \%$ (i.e. 618/7536). The response rates with and without bounce emails were 3.91\% (295/7536) and 4.26\% (295/6918). Male: female ratio was 2.78 (217:78). The majority responses obtained were from private institutes i.e. $89.8 \%(n=265)$ while the responses from government and semi-government institutes were $7.79 \%(\mathrm{n}=23)$ and $2.37 \%(\mathrm{n}=7)$ respectively.

According to Raosoft calculator, margin of error for the current sample size (i.e. 295) was $5.66 \%$, with confidence level $95 \%$ and response distribution of $50 \%{ }^{13}$ The Cronbach's alpha value (internal consistency) for the survey instrument was $0.89 .{ }^{12}$ Other results of the study including question category, question, options, number of responses and their percentages were as shown in the Table 2. The average values for the parameters evaluating research productivity are as mentioned in Table 3.

\section{DISCUSSION}

Pharmacy faculties have rarely been surveyed in India. To the best of our knowledge, the current study was the first Indian study focused on assessing the multiple factors associated with research involvement and productivity of pharmacy faculties.

We could find only 3 studies in India that surveyed pharmacy faculties i.e. Ahmad et al $(2015,2016) \cdot{ }^{14,15}$ and Durai et al. (2016). ${ }^{16}$ Ahmad et al (2015) [14] assessed the level of workload and satisfaction of faculties in public and private pharmacy institutes. Ahmad et al (2016). ${ }^{15}$ evaluated the level of job satisfaction among Indian pharmacists. Whereas Durai et al (2016). ${ }^{16}$ weighed up the perspectives of pharmacy students and faculties about social networking sites.

Sharma et al study. ${ }^{17}$ has reported that Indian academicians are less responsive to emails. We also came across the same in our study; the response rate observed was also far less i.e. 3.91\%. Whereas, the response rates in Ahmad et al study (2015). ${ }^{14}$ was $44.39 \%$, and in Durai et al study it was $44.44 \%$. As per PCI website, total 2767 pharmacy institutes exist in India; out of which we could reach 108 institutes for this survey.

Sharma et al. ${ }^{17}$ targeted to determine e-literacy and perception of priority of senior Indian academicians. The proportion of bounce emails reported in the study was $9 \%$ while we report the percentage to be $8.2 \%$. 


\begin{tabular}{|c|c|c|c|}
\hline Question & Options & $\mathbf{N}$ & $\%$ \\
\hline I am a/an & $\begin{array}{c}\text { Lecturer } \\
\text { Assistant Professor } \\
\text { Associate Professor } \\
\text { Professor } \\
\text { HOD/Vice principal } \\
\text { Principal/Dean } \\
\text { Director/Vice chancellor }\end{array}$ & $\begin{array}{c}26 \\
110 \\
64 \\
28 \\
30 \\
33 \\
04\end{array}$ & $\begin{array}{c}8.81 \\
37.29 \\
21.69 \\
9.49 \\
10.17 \\
11.19 \\
1.36\end{array}$ \\
\hline $\begin{array}{l}\text { My highest educational qualification } \\
\text { is }\end{array}$ & $\begin{array}{c}\text { B. Pharm } \\
\text { Post graduate diploma } \\
\text { MPharm/MS/MBA/M Tech/MSc } \\
\text { PharmD/PharmD (PB) } \\
\text { PhD } \\
\text { Post doc fellowship }\end{array}$ & $\begin{array}{c}2 \\
1 \\
108 \\
6 \\
166 \\
12\end{array}$ & $\begin{array}{c}0.68 \\
0.34 \\
36.61 \\
2.03 \\
56.27 \\
4.07\end{array}$ \\
\hline $\begin{array}{l}\text { My pharmacy institute is located in } \\
\text { state/union territory of India. }\end{array}$ & $\begin{array}{c}\text { AP } \\
\text { AS } \\
\text { BR } \\
\text { CG } \\
\text { DL } \\
\text { GJ } \\
\text { KL } \\
\text { KN } \\
\text { MH } \\
\text { MP } \\
\text { OD } \\
\text { PB } \\
\text { RJ } \\
\text { TG } \\
\text { TN } \\
\text { UK } \\
\text { UP } \\
\text { WB }\end{array}$ & $\begin{array}{c}28 \\
1 \\
1 \\
1 \\
1 \\
25 \\
5 \\
47 \\
94 \\
10 \\
3 \\
10 \\
3 \\
22 \\
30 \\
1 \\
11 \\
2\end{array}$ & $\begin{array}{c}9.49 \\
0.34 \\
0.34 \\
0.34 \\
0.34 \\
8.47 \\
1.69 \\
15.93 \\
31.86 \\
3.39 \\
1.02 \\
3.39 \\
1.02 \\
7.46 \\
10.17 \\
0.34 \\
3.73 \\
0.68\end{array}$ \\
\hline $\begin{array}{l}\text { I teach/administer or have taught/ } \\
\text { administered ___udents. }\end{array}$ & $\begin{array}{c}\text { D. Pharm } \\
\text { B. Pharm } \\
\text { M. Pharm } \\
\text { Post graduate diploma } \\
\text { PharmD } \\
\text { PharmD (PB) } \\
\text { PhD } \\
\text { Post doctoral }\end{array}$ & $\begin{array}{c}71 \\
254 \\
212 \\
8 \\
114 \\
35 \\
70 \\
5\end{array}$ & $\begin{array}{c}9.23 \\
33.03 \\
27.57 \\
1.04 \\
14.82 \\
4.55 \\
9.10 \\
0.65\end{array}$ \\
\hline Since $\_$years I am in teaching & $\begin{array}{c}\leq 5 \text { years } \\
6-10 \text { years } \\
11-20 \text { years } \\
21-30 \text { years } \\
31-40 \text { years } \\
41-50 \text { years } \\
51-70 \text { years }\end{array}$ & $\begin{array}{c}53 \\
89 \\
111 \\
35 \\
6 \\
0 \\
1\end{array}$ & $\begin{array}{l}17.97 \\
30.17 \\
37.63 \\
11.86 \\
2.03 \\
0.00 \\
0.34\end{array}$ \\
\hline My area of interest for research is & $\begin{array}{c}\text { Pharmaceutics/Formulation/Manufacturing } \\
\text { Pharmacology/Toxicology (preclinical) } \\
\text { Pharmacognosy/Natural products/Drug discovery } \\
\text { Pharmaceutical Chemistry } \\
\text { Pharmacy Practice/Clinical Pharmacy } \\
\text { Pharmaceutical analysis } \\
\text { Pharmaceutical Biotechnology } \\
\text { Pharmaceutical Marketing/Administration } \\
\text { Drug regulatory affairs } \\
\text { Pharmacoinformatics/Drug designing } \\
\text { Other }^{1}\end{array}$ & $\begin{array}{l}64 \\
57 \\
38 \\
54 \\
32 \\
24 \\
10 \\
02 \\
04 \\
04 \\
06\end{array}$ & $\begin{array}{l}21.69 \\
19.32 \\
12.88 \\
18.31 \\
10.85 \\
8.14 \\
3.39 \\
0.68 \\
1.36 \\
1.36 \\
2.03\end{array}$ \\
\hline
\end{tabular}

Continued... 


\begin{tabular}{|c|c|c|c|}
\hline I am involved in __ type of research. & $\begin{array}{c}\text { Academic/Laboratory } \\
\text { Industrial } \\
\text { Clinical/practice oriented } \\
\text { Academic }+ \text { Clinical/practice oriented } \\
\text { Academic + Industrial } \\
\text { Academic + Industrial +Clinical/practice oriented }\end{array}$ & $\begin{array}{l}239 \\
02 \\
16 \\
14 \\
18 \\
6\end{array}$ & $\begin{array}{l}81.02 \\
0.68 \\
5.42 \\
4.75 \\
6.10 \\
2.03\end{array}$ \\
\hline $\begin{array}{l}\text { How much of research grants have you } \\
\text { received until now? }\end{array}$ & $\begin{array}{c}\text { No grants } \\
\leq 1 \text { lakh } \\
1,00,001-5,00,000 \\
5,00,001-10,00,000 \\
10,00,001-30,00,000 \\
30,00,001-50,00,000 \\
50,00,001-1 \text { crore } \\
1 \text { crore }-5 \text { crore } \\
5.1-10 \text { crore } \\
>10.1 \text { crore }\end{array}$ & $\begin{array}{c}142 \\
36 \\
45 \\
27 \\
24 \\
9 \\
7 \\
3 \\
1 \\
1\end{array}$ & $\begin{array}{l}48.14 \\
12.20 \\
15.25 \\
9.15 \\
8.14 \\
3.05 \\
2.37 \\
1.02 \\
0.34 \\
0.34\end{array}$ \\
\hline $\begin{array}{l}\text { Were/Are you a member of research } \\
\text { committee of the university/institute? }\end{array}$ & $\begin{array}{l}\text { Yes } \\
\text { No }\end{array}$ & $\begin{array}{l}132 \\
163\end{array}$ & $\begin{array}{l}44.75 \\
55.25\end{array}$ \\
\hline $\begin{array}{c}\text { On an average, how much time do you } \\
\text { spend on "research/research related } \\
\text { activities" a day? }\end{array}$ & $\begin{array}{l}\text { Zero } \\
\leq 1 \mathrm{~h} \\
1 \mathrm{~h} 1 \mathrm{~min}-2 \mathrm{~h} \\
2 \mathrm{~h} 1 \mathrm{~min}-3 \mathrm{~h} \\
3 \mathrm{~h} 1 \mathrm{~min}-5 \mathrm{~h} \\
5 \mathrm{~h} 1 \mathrm{~min}-8 \mathrm{~h} \\
8 \mathrm{~h} 1 \mathrm{~min}-12 \mathrm{~h} \\
12 \mathrm{~h} 1 \mathrm{~min}-20 \mathrm{~h}\end{array}$ & $\begin{array}{l}13 \\
54 \\
98 \\
77 \\
37 \\
12 \\
2 \\
2\end{array}$ & $\begin{array}{l}4.41 \\
18.31 \\
33.22 \\
26.10 \\
12.54 \\
4.07 \\
0.68 \\
0.68\end{array}$ \\
\hline $\begin{array}{l}\text { Currently I am working on } \\
\text { research projects that are in pipeline/are } \\
\text { unpublished/ongoing. }\end{array}$ & $\begin{array}{l}\text { Zero } \\
\leq 3 \\
4-5 \\
6-10 \\
11-20\end{array}$ & $\begin{array}{c}60 \\
177 \\
36 \\
21 \\
1\end{array}$ & $\begin{array}{l}20.34 \\
60.00 \\
12.20 \\
7.12 \\
0.34\end{array}$ \\
\hline \multirow[t]{2}{*}{$\begin{array}{l}\text { India has got hundreds of pharmacy } \\
\text { institutes but our global contribution } \\
\text { in research is negligible. What are the } \\
\text { possible reasons according to you? }\end{array}$} & $\begin{array}{c}\text { Faculties are unable to spend time on research } \\
\text { Less/no research grants/financial support } \\
\text { Less/no interest in research } \\
\text { Less/no guidance on research publication } \\
\text { Less/no environment for research } \\
\text { Less/no research facilities e.g. laboratories } \\
\text { Other }{ }^{2}\end{array}$ & $\begin{array}{c}186 \\
167 \\
69 \\
71 \\
144 \\
144 \\
24\end{array}$ & $\begin{array}{c}23.11 \\
20.75 \\
8.57 \\
8.82 \\
17.89 \\
17.89 \\
2.98\end{array}$ \\
\hline & Total & 805 & 100 \\
\hline \multirow[t]{2}{*}{$\begin{array}{l}\text { What will you recommend to increase } \\
\text { and improve the research conducted by } \\
\text { pharmacy faculties? }\end{array}$} & $\begin{array}{c}\text { Increments/promotion based on number of publications } \\
\text { Increments/promotions based on number of publications } \\
\text { as the first author } \\
\text { Govt. authorities should provide more grants } \\
\text { Regulation should be there for faculties to spend more } \\
\text { time on research } \\
\text { Laboratories should be made full fledge } \\
\text { Stringent rules to avoid manipulation of the research } \\
\text { Other }{ }^{3}\end{array}$ & $\begin{array}{c}149 \\
111 \\
161 \\
178 \\
194 \\
148 \\
26\end{array}$ & $\begin{array}{l}15.41 \\
11.48 \\
16.65 \\
18.41 \\
20.06 \\
15.31 \\
2.69\end{array}$ \\
\hline & Total & 967 & 100 \\
\hline \multirow[t]{2}{*}{$\begin{array}{l}\text { Students are future faculties. What will } \\
\text { you recommend to increase student } \\
\text { involvement in research? }\end{array}$} & $\begin{array}{c}\text { Stories of scientists/inventions should be there in the } \\
\text { syllabus } \\
\text { PhDs must be awarded based on no. of publications } \\
\text { e.g. } 1 \mathrm{PhD}=\text { Min } 5 \text { publications } \\
\text { Better stipend/scholarships for research scholars } \\
\text { Faculties should become the role models in research } \\
\text { Other }\end{array}$ & $\begin{array}{c}96 \\
144 \\
186 \\
215 \\
26 \\
\end{array}$ & $\begin{array}{c}14.39 \\
21.59 \\
27.89 \\
32.23 \\
3.90\end{array}$ \\
\hline & Total & 667 & 100 \\
\hline
\end{tabular}

Continued... 


\section{Table 2: Cont'd.}

$\mathrm{AP}=$ Andhra Pradesh; $\mathrm{AS}=$ Assam; $\mathrm{BR}=$ Bihar; $\mathrm{CG}=$ Chhatisgarh; $\mathrm{DL}=$ Delhi; GJ= Gujarat; $\mathrm{KL}=$ Kerala; $\mathrm{KN}=\mathrm{Karnataka}$; MH= Maharashtra; MP= Madhya Pradesh; OD= Odisha; PB= Punjab; RJ= Rajasthan; TG=Telangana; TN=Tamilnadu; UK= Uttarakhand; UP= Uttar Pradesh; WB= West Bengal; HOD= Head of the Department

1: Pharmacokinetics and metabolism; General issues; Pharmaceutics and biotechnology; Pharmaceutical analysis and medicinal chemistry; Pharmaceutical microbiology (2). 2: No motivation (3); Skills of faculties are being used for some other reasons e.g. admission procedure; No support from management (2); Manipulation in research (2); Institutes are behind admissions and not research (2); Semester pattern; Different inspections e.g. NBA, NAAC, AICTE, PCl etc (2); Overloaded with classes (3); Limited access to research articles; Politics in faculties; Corruption; No open minded people; No high salaries for researchers; Quality young research students are not available; People are running behind publications and not research outputs; Caste based reservations

3: Proper and high salary structure for researchers should be there (2); Faculties interested in research should only be persuaded for research; One faculty should guide maximum 2 students for PhD; Less/no politics; Pharmacy associations should provide the grants; Quality publications are needed rather than quantity; Other type of work by faculties should be reduced e.g. Extracurricular activities; Regular teaching workload should be reduced; Faculties should spend free time while reading research articles; Plagiarism checking should be conducted for all researches; Student-authored publications should also be considered; The quality researchers should have world class research facilities; Faculty selection in a college should be based on performance in research; Promotion should be based on impact factor; No rule should be there as it may lead to useless projects; Create environment for research; Seniors faculties should involve junior faculties as a co-investigator; Non reputed journals must be strictly discouraged; Research based training is needed (2); The approval for an institute should be based on research productivity; The funding agencies should consider the research proposals from new investigators and private institutions too; Should have such surveys every time; The universities should encourage faculty research

4: Quality students should be focused (2); Quality of research should be focused over quantity; Need to identify the skilled research students well in advance; Honesty and quality should be inculcated; Improved employment opportunities in government sectors; interdisciplinary research should be enhanced; Annual pattern should be followed over semester one (4); The basics of the course should be focused; Well indexed journals should only be followed (2); Paid journals should be avoided; Off campus PhD shouldn't be there; Faculties must be deputed to government labs; Students should be encouraged to participate in national and international research events; Students should be given the financial support; Research assistance should be provided to PG students; Regular research events should be conducted in the institute; Research based recruitments and appraisals should be there; Research projects should be promoted as a part of UG studies; Stringent rules should be made for a PhD candidate; Quality guidance should be provided; Students should be motivated etc.

According to AACP (American Association of Colleges of Pharmacy) faculty survey 2016. ${ }^{18} 59.3 \%$ faculties have reported that they spend 'appropriate' time on research. In India, the average time spent on research by faculty in private institute is $9.12 \mathrm{~h} /$ week while in government institute it is $14.51 \mathrm{~h} /$ week. $^{14}$ Our study reports the average time spent for research/related activities as $2.19 \mathrm{~h} /$ day (131.56 $\mathrm{min} /$ day).

The conferences attended by faculties in private and the government institutes are 2.55/year and 2.83/year respectively. ${ }^{14}$ We found the conferences attended by faculties to be 1.96/year [Average conferences attended $(24.58) \div$ (Average experience) 12.51$]$.

According to Ahmad et al study, ${ }^{14} 52.60 \%$ faculties disagree to the question 'workload affects research capabilities'. We found that $23.11 \%$ faculties have given this as a reason for less research productivity of India at global platform. Academicians' job satisfaction levels are the highest among the types of pharmacists in India. ${ }^{15}$ At the same time, the faculties in our survey have given a variety of reasons for unsatisfactory pharmacy research performance of India at international level. [Table 2] Ahmadian $e t a l^{19}$ have analyzed the number of research publications, patents, and H-index values (in pharmacy field) of 102 countries. As per the study, India's total number of pharmacy related publications, $h$ index and patents were 55044, 108 and 836 respectively. The numbers are far less than the developed countries in the world. In our study, the average number of publications per faculty, $h$ index and patents were 34.30, 8.99 and 0.90 respectively. The average numbers of $\mathrm{i}-10$ index and total citations we obtained were- 5.76 and 156.96 respectively. [Table 4] We also determined the average values for certain parameters determining the research credibility of a faculty like- years of experience in teaching/research, research grants received, time spent by a faculty for research or related activities, and the number of ongoing research projects and the average values were- 12.51 years, 16.5 lakhs, $131.56 \mathrm{~min} /$ day and 2.37 respectively. [Table 5]

Indexing of a journal is one of the important factors for considering the quality of research. PubMed is a reputed, the most widely used biomedical bibliographic database and maintains a dominant position in the field. ${ }^{20}$ In short, the journals indexed with PubMed are considered to be good. ${ }^{21}$ Furthermore, Vinod et al. ${ }^{10}$ have recommended that Indian journals should come under reputed databases. By considering this scenario we asked the question 'How many of your research publications are indexed with PubMed/Medline?'. The average PubMed indexed publications in our study were 15.71 .

Dotson study ${ }^{22}$ has found that the editorial board members (EBMs) of many leading international pharmacy journals have a very small number $(<2 \%)$ of the members from lower- and middle-income countries. In our study, we observed that the faculty has been an EBM of 3.08 journals on an average. Therefore, we suspect the responders to be the EBMs of national/non-leading journals in pharmacy.

According to AACP preceptor survey 2016. ${ }^{23}$, the majority of the preceptors had guided PharmD students $(n=4282)$, followed by BS Pharm $(\mathrm{n}=2221)$ and residency programs $(n=1689)$. We found the average number of undergrad- 


\begin{tabular}{|c|c|c|c|c|c|c|c|c|c|c|c|c|c|c|c|c|}
\hline \multicolumn{2}{|c|}{ 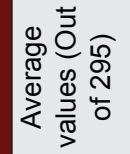 } & $\begin{array}{l}\text { ᄋ్m } \\
\text { 户े }\end{array}$ & $\begin{array}{l}\stackrel{P}{+} \\
\underset{\leftarrow}{+}\end{array}$ & $\begin{array}{l}\infty \\
\stackrel{\infty}{\infty} \\
\text { '. }\end{array}$ & $\stackrel{\text { Oִ }}{r}$ & $\stackrel{m}{\stackrel{m}{m}}$ & $\begin{array}{l}\infty \\
i \\
\stackrel{\sim}{\sim} \\
\dot{\sim}\end{array}$ & $\underset{\infty}{\underset{\infty}{\infty}}$ & $\stackrel{\bar{c}}{\grave{N}}$ & $\begin{array}{l}\& \\
\stackrel{\sim}{0}\end{array}$ & $\begin{array}{l}8 \\
0 \\
0\end{array}$ & $\underset{+}{\stackrel{+}{+}}$ & $\stackrel{\infty}{\stackrel{\infty}{\sim}}$ & $\begin{array}{l}\infty \\
\infty \\
0 \\
0\end{array}$ & \&্ণ & $\begin{array}{l}\overline{\hat{\sigma}} \\
\stackrel{\omega}{\circ}\end{array}$ \\
\hline \multicolumn{2}{|c|}{ 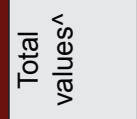 } & $\stackrel{\circ}{\stackrel{0}{\circ}}$ & $\stackrel{\stackrel{L}{\stackrel{N}{N}}}{\stackrel{\sim}{\sim}}$ & $\begin{array}{l}\text { டீ. } \\
\text { هి }\end{array}$ & $\begin{array}{l}\stackrel{n}{i} \\
\stackrel{N}{\hat{N}}\end{array}$ & $\stackrel{\infty}{\infty}$ & $\begin{array}{l}n \\
\stackrel{0}{0} \\
\stackrel{1}{N} \\
N\end{array}$ & $\stackrel{\widetilde{N}}{\underset{N}{N}}$ & $\begin{array}{l}10 \\
\infty \\
0 \\
0\end{array}$ & 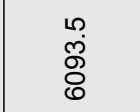 & $\begin{array}{l}\stackrel{\rho}{0} \\
\stackrel{\mathscr{Q}}{N}\end{array}$ & $\begin{array}{l}\stackrel{\infty}{్} \\
\stackrel{్}{~}\end{array}$ & 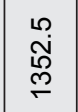 & & 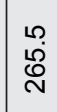 & $\begin{array}{l}\stackrel{L}{0} \\
\stackrel{\rho}{0} \\
\mathscr{\sigma}\end{array}$ \\
\hline \multirow{2}{*}{ 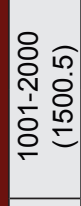 } & $0^{\circ}$ & \&̊․ & $\stackrel{0}{0}$ & $\stackrel{8}{0}$ & : & 心్ల. & $\stackrel{8}{\circ}$ & : & $\stackrel{\circ}{\circ}$ & $\stackrel{\circ}{\circ}$ & $\stackrel{\circ}{\circ}$ & : & $\stackrel{\circ}{\circ}$ & : & $\stackrel{8}{\circ}$ & $\stackrel{\circ}{\circ}$ \\
\hline & $z$ & 0 & 0 & 0 & 0 & $r$ & 0 & 0 & 0 & 0 & 0 & 0 & 0 & 0 & 0 & 0 \\
\hline \multirow{2}{*}{ 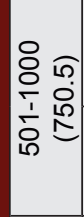 } & $\therefore$ & @: & \&: & \&: & $\stackrel{8}{\circ}$ & $\stackrel{\overbrace{}}{\stackrel{\sigma}{\leftarrow}}$ & \& & \&: & ঙ্ & $\stackrel{8}{\circ}$ & $\stackrel{8}{\circ}$ & \&: & $\stackrel{8}{\circ}$ & \&: & $\stackrel{8}{0}$ & \&: \\
\hline & $z$ & 0 & 0 & 0 & 0 & $m$ & 0 & 0 & $r$ & 0 & 0 & 0 & 0 & 0 & 0 & 0 \\
\hline \multirow{2}{*}{$\begin{array}{lll}0 & \\
0 & 0 \\
0 & 0 \\
1 & 0 \\
0 & 0 \\
& 0\end{array}$} & $\circ^{\circ}$ & $\stackrel{\stackrel{\mathscr{R}}{\leftarrow}}{\stackrel{f}{\circ}}$ & \begin{tabular}{l}
$\infty$ \\
\hdashline \\
0
\end{tabular} & ¿̊. & ֻే & $\stackrel{\mathscr{\rho}}{\text { m. }}$ & $\stackrel{g}{\stackrel{\leftrightarrow}{\circ}}$ & $\begin{array}{l}\stackrel{\infty}{0} \\
\stackrel{0}{0}\end{array}$ & 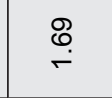 & $\stackrel{\infty}{\text { N }}$ & $\stackrel{\circ}{\circ}$ & : & : & 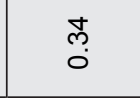 & $\stackrel{\circ}{\circ}$ & 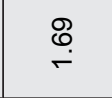 \\
\hline & $z$ & $\underset{\leftarrow}{\triangleright}$ & $\sim$ & 0 & - & $\sigma$ & م & $\sim$ & م & 0 & 0 & 0 & 0 & - & 0 & 60 \\
\hline \multirow{2}{*}{ 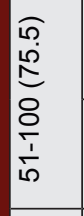 } & $\therefore$ & $\stackrel{g}{\circ}$ & $\begin{array}{l}\hat{\sigma} \\
\dot{\sigma}\end{array}$ & ల్ల & $\begin{array}{l}\infty \\
0 \\
0\end{array}$ & $\stackrel{i}{\Lambda}$ & $\begin{array}{l}0 \\
2 \\
i \infty\end{array}$ & $\begin{array}{l}\infty \\
0 \\
0\end{array}$ & $\begin{array}{l}\infty \\
\text { ¿ }\end{array}$ & $\underset{\text { m్ }}{\text { p. }}$ & $\stackrel{\widehat{N}}{\text { in }}$ & $\stackrel{\text { ָ̦ }}{\leftarrow}$ & 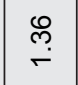 & $\stackrel{\text { No }}{r}$ & \&: & $\begin{array}{l}\hat{O} \\
\dot{\forall}\end{array}$ \\
\hline & $z$ & $\stackrel{\infty}{N}$ & $\stackrel{\simeq}{\simeq}$ & $r$ & $N$ & $\infty$ & 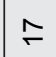 & $\sim$ & $\stackrel{20}{\sim}$ & 음 & $\wedge$ & $m$ & $\nabla$ & $m$ & 0 & $\cong$ \\
\hline \multirow{2}{*}{ 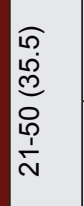 } & ㅇ & $\begin{array}{l}\infty \\
\stackrel{i}{0} \\
\stackrel{i}{0}\end{array}$ & 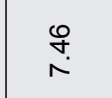 & $\begin{array}{l}\infty \\
\stackrel{0}{0} \\
0\end{array}$ & $\stackrel{\hat{\sigma}}{\circ}$ & $\begin{array}{l}\infty \\
\infty \\
\infty \\
\infty\end{array}$ & $\begin{array}{l}\hat{O} \\
\dot{\sim}\end{array}$ & 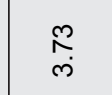 & $\begin{array}{l}50 \\
\stackrel{0}{\circ}\end{array}$ & $\begin{array}{l}\text { 乃 } \\
\stackrel{\circ}{\circ}\end{array}$ & 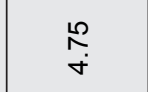 & $\stackrel{i}{i}$ & $\stackrel{\text { ֻ }}{\text { ஸे }}$ & $\begin{array}{l}\infty \\
\stackrel{0}{0} \\
0\end{array}$ & 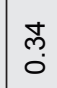 & 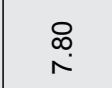 \\
\hline & z & $\overline{0}$ & N & $\sim$ & $\stackrel{ }{\sim}$ & 尺 & $\bar{r}$ & $\mp$ & $\bar{m}$ & $\hat{\forall}$ & $\stackrel{\nabla}{\square}$ & $\infty$ & 0 & $N$ & - & $\stackrel{N}{N}$ \\
\hline \multirow{2}{*}{ 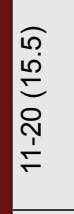 } & ๙0 & $\begin{array}{l}\bar{N} \\
\mathbb{N}\end{array}$ & $\begin{array}{l}\hat{o} \\
\dot{d}\end{array}$ & $\stackrel{\widehat{m}}{\sim}$ & $\begin{array}{l}\bar{\infty} \\
\infty \\
\infty\end{array}$ & $\begin{array}{l}0 \\
\stackrel{\circ}{0} \\
\stackrel{\sim}{\circ}\end{array}$ & $\begin{array}{l}n \\
\infty \\
0 \\
0\end{array}$ & $\stackrel{\mathscr{R}}{\stackrel{R}{F}}$ & $\begin{array}{l}\stackrel{8}{\mathrm{~N}} \\
\grave{\dot{n}}\end{array}$ & $\begin{array}{l}\text { లె } \\
\text { స్ }\end{array}$ & $\begin{array}{l}\text { లె } \\
\text { ¿ें }\end{array}$ & $\stackrel{\infty}{\stackrel{\infty}{0}}$ & $\begin{array}{l}\infty \\
\stackrel{\infty}{\circ} \\
\text { م. }\end{array}$ & $\begin{array}{l}\infty \\
\infty \\
\stackrel{0}{0}\end{array}$ & ङे & $\begin{array}{l}\text { 乃 } \\
\stackrel{\rho}{\rho}\end{array}$ \\
\hline & $z$ & $\hat{0}$ & $\bar{r}$ & $\wedge$ & $\stackrel{\leftrightarrow}{N}$ & 우 & б & ఉ్ల & ఫే & 8 & 8 & ㅇ & $\stackrel{10}{\leftarrow}$ & స్ & - & 守 \\
\hline \multirow{2}{*}{ 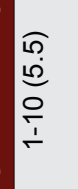 } & ㅇ & $\begin{array}{l}\overline{0} \\
\dot{\phi}\end{array}$ & $\begin{array}{l}0 \\
\text { மூ } \\
\end{array}$ & $\begin{array}{l}\text { ले } \\
\text { gे }\end{array}$ & $\begin{array}{l}\bar{\infty} \\
\infty \\
\stackrel{\infty}{\sigma}\end{array}$ & $\stackrel{\text { n) }}{\stackrel{N}{N}}$ & $\begin{array}{l}\infty \\
\infty \\
\\
\end{array}$ & $\begin{array}{l}\stackrel{J}{0} \\
\dot{\theta}\end{array}$ & $\begin{array}{l}\bar{y} \\
\dot{y}\end{array}$ & $\stackrel{\text { L }}{\stackrel{\sigma}{\sigma}}$ & $\begin{array}{l}\hat{\overbrace{}} \\
\text { }\end{array}$ & $\begin{array}{l}\text { مी } \\
\text { مُ }\end{array}$ & $\begin{array}{l}\stackrel{N}{N} \\
\stackrel{m}{m}\end{array}$ & $\begin{array}{l}0 \\
\text { in }\end{array}$ & $\begin{array}{l}\tilde{N} \\
\stackrel{N}{m}\end{array}$ & 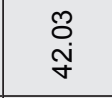 \\
\hline & $z$ & $\stackrel{\infty}{\circ}$ & $\stackrel{\infty}{\stackrel{\infty}{\rho}}$ & $\stackrel{\stackrel{g}{ }}{\Gamma}$ & $\underset{\sim}{\stackrel{\Xi}{ }}$ & 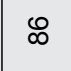 & ò & 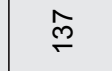 & $\bar{m}$ & $\stackrel{\llcorner O}{\sim}$ & $\stackrel{\square}{\underset{\infty}{\circ}}$ & $\stackrel{\stackrel{\varrho}{\circ}}{\sim}$ & 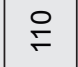 & $\stackrel{R}{r}$ & థి & $\stackrel{\unlhd}{\stackrel{ \pm}{V}}$ \\
\hline \multirow{2}{*}{ ô } & $\therefore$ & $\begin{array}{l}\stackrel{0}{0} \\
i\end{array}$ & $\stackrel{ }{\circ}$ & $\begin{array}{l}\text { No } \\
0 \\
i\end{array}$ & 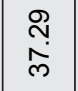 & $\begin{array}{l}\text { ले } \\
\text { ơ }\end{array}$ & $\stackrel{\stackrel{R}{R}}{\stackrel{f}{\sigma}}$ & 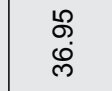 & $\begin{array}{l}\hat{N} \\
0\end{array}$ & $\stackrel{\circ}{\stackrel{0}{0}}$ & $\stackrel{ }{\circ}$ & $\begin{array}{l}\text { \& } \\
\text { ஸ̉ }\end{array}$ & $\begin{array}{l}\stackrel{J}{+} \\
\stackrel{5}{\circ}\end{array}$ & $\begin{array}{l}\stackrel{9}{+} \\
\underset{N}{N}\end{array}$ & $\begin{array}{l}\stackrel{ }{\dot{8}} \\
\stackrel{\infty}{0}\end{array}$ & $\begin{array}{l}\stackrel{\infty}{\infty} \\
\stackrel{5}{*}\end{array}$ \\
\hline & $z$ & $\stackrel{\curvearrowright}{\circ}$ & ిల & 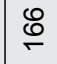 & $\stackrel{ }{ }$ & $\stackrel{\stackrel{\rho}{\digamma}}{\circ}$ & $\underset{\leftarrow}{\triangleright}$ & $\stackrel{\circ}{\circ}$ & $\stackrel{\infty}{+}$ & $\stackrel{\infty}{\sim}$ & ిల & 욤 & $\stackrel{\circ}{\circ}$ & $\widehat{\infty}$ & 点 & 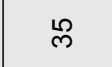 \\
\hline $\begin{array}{l}\uparrow \\
\sum_{\infty} \\
0 \\
\frac{0}{0} \\
\overline{0} \\
0\end{array}$ & 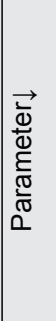 & 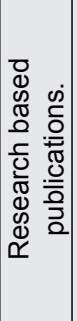 & 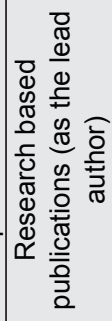 & 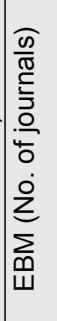 & 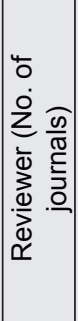 & 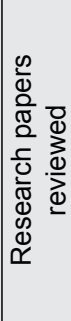 & 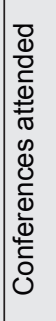 & 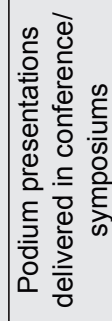 & 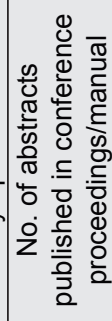 & 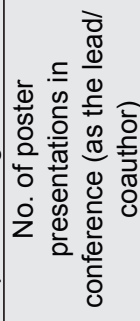 & 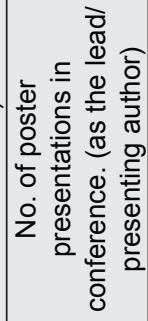 & 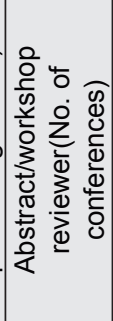 & 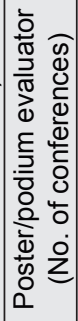 & 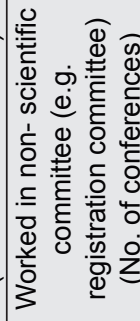 & 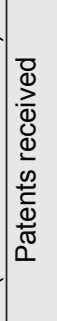 & 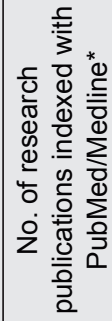 \\
\hline
\end{tabular}




\begin{tabular}{|c|c|c|c|c|c|}
\hline 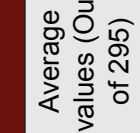 & $\begin{array}{c}\bar{\oplus} \\
\dot{m}\end{array}$ & $\begin{array}{l}\stackrel{\mathscr{\infty}}{ } \\
\text { Ni }\end{array}$ & $\begin{array}{l}\underset{N}{\infty} \\
\stackrel{\infty}{\sim}\end{array}$ & $\stackrel{\hat{\leftrightarrow}}{\stackrel{\sim}{v}}$ & 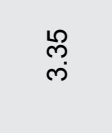 \\
\hline 高 & 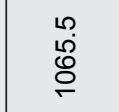 & $\begin{array}{l}0 \\
\text { ô }\end{array}$ & $\begin{array}{l}\text { مొ } \\
\text { గొ }\end{array}$ & $\stackrel{\infty}{\infty}$ & $\widehat{\infty}$ \\
\hline \multirow{2}{*}{ 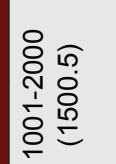 } & $\begin{array}{l}8 \\
0\end{array}$ & ঙ্ & : & : & $\begin{array}{l}8 \\
0 \\
0\end{array}$ \\
\hline & 0 & - & 0 & 0 & 0 \\
\hline \multirow{2}{*}{ 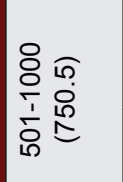 } & $\stackrel{8}{0}$ & \begin{tabular}{l}
$\infty$ \\
\hdashline \\
0
\end{tabular} & $\stackrel{8}{0}$ & ৪ & $\stackrel{8}{\circ}$ \\
\hline & 0 & $\sim$ & 0 & 0 & 0 \\
\hline \multirow{2}{*}{ 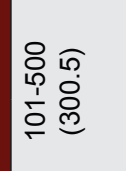 } & $\stackrel{8}{8}$ & $\stackrel{\text { ஜ̊ }}{\text { p. }}$ & $\stackrel{\sim}{\stackrel{\sim}{*}}$ & ఝे & ले \\
\hline & 0 & a & m & - & - \\
\hline \multirow{2}{*}{$\begin{array}{l}10 \\
10 \\
\frac{1}{5} \\
8 \\
\frac{1}{10} \\
\frac{1}{10}\end{array}$} & $\stackrel{8}{0}$ & $\begin{array}{l}\text { ָै } \\
\text { iึ }\end{array}$ & 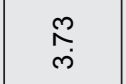 & \&: & ঙ্ \\
\hline & 0 & $\stackrel{\circ}{\circ}$ & $F$ & 0 & - \\
\hline \multirow{2}{*}{ 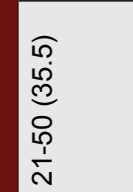 } & $\stackrel{\leftrightarrow}{\stackrel{\leftrightarrow}{r}}$ & $\begin{array}{l}\infty \\
\stackrel{\infty}{\mathfrak{I}} \\
\stackrel{2}{2}\end{array}$ & $\begin{array}{l}\text { ల్ } \\
\text { ָे }\end{array}$ & $\stackrel{\sim}{\stackrel{\sim}{r}}$ & $\stackrel{\text { ș }}{r}$ \\
\hline & $\nabla$ & $\stackrel{\infty}{m}$ & 8 & $m$ & $m$ \\
\hline \multirow{2}{*}{ 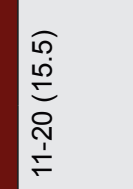 } & $\stackrel{\text { O̊ }}{\text { in }}$ & $\begin{array}{l}\infty \\
\stackrel{\infty}{\infty} \\
\infty\end{array}$ & $\begin{array}{l}\hat{N} \\
\stackrel{\sigma}{\sigma}\end{array}$ & $\begin{array}{l}\infty \\
\text { O } \\
\text { iे }\end{array}$ & 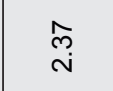 \\
\hline & 0 & ஜீ & $\stackrel{\infty}{\stackrel{\sim}{*}}$ & $\stackrel{\llcorner}{\leftarrow}$ & $\wedge$ \\
\hline \multirow{2}{*}{ 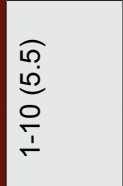 } & $\frac{\circ}{\dot{5}}$ & $\begin{array}{l}\stackrel{\sim}{N} \\
\stackrel{w}{m}\end{array}$ & $\underset{\infty}{\stackrel{\nabla}{\infty}}$ & $\frac{\infty}{\sigma}$ & $\begin{array}{l}\overline{+} \\
\stackrel{\sim}{\sim}\end{array}$ \\
\hline & $\stackrel{5}{\leftarrow}$ & $\stackrel{\text { O }}{\circ}$ & $\infty$ & $\hat{N}$ & $\stackrel{N}{ }$ \\
\hline \multirow{2}{*}{$\begin{array}{l}\widehat{o} \\
0\end{array}$} & $\begin{array}{l}\mathcal{f} \\
\stackrel{f}{f}\end{array}$ & 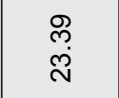 & $\begin{array}{l}0 \\
\stackrel{N}{N}\end{array}$ & $\begin{array}{l}\overline{+} \\
\dot{\infty}\end{array}$ & 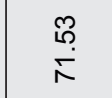 \\
\hline & $\stackrel{m}{\longrightarrow}$ & 8 & $\bar{\infty}$ & $\stackrel{g}{\sim}$ & $\bar{\Sigma}$ \\
\hline 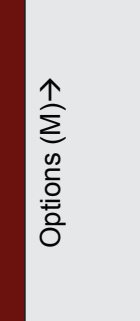 & 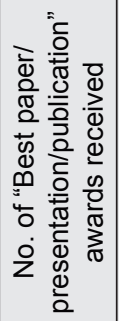 & 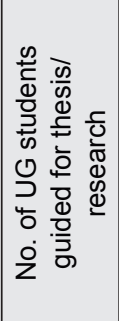 & 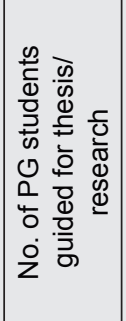 & 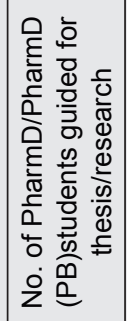 & 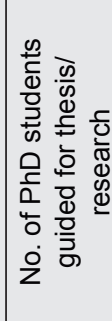 \\
\hline
\end{tabular}

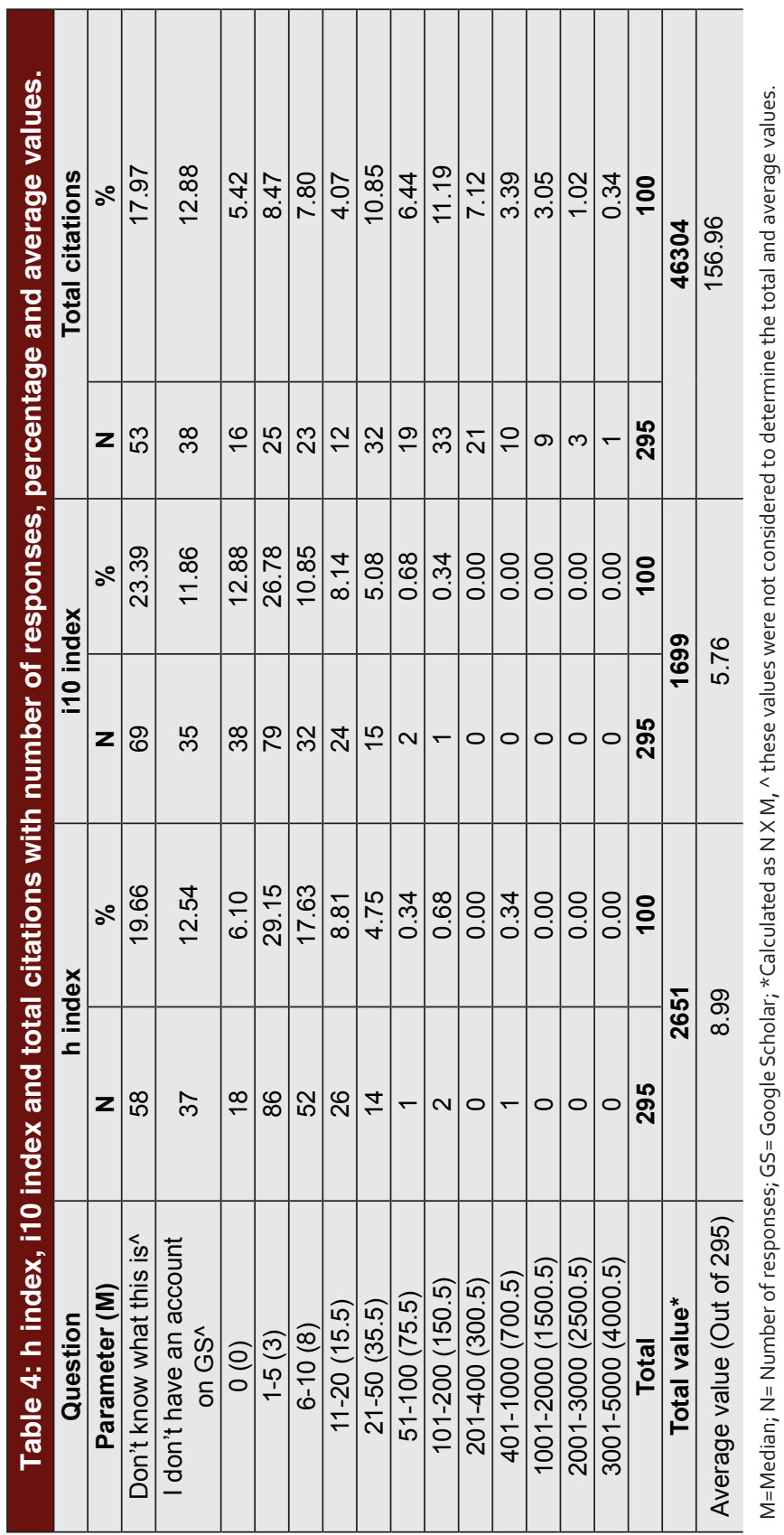




\begin{tabular}{|c|c|c|c|c|c|c|c|}
\hline Parameter & Lower limit & Upper limit & Median (M) & $\begin{array}{l}\text { No. of } \\
\text { responses } \\
\text { (N) }\end{array}$ & $M \times N$ & Total value & $\begin{array}{c}\text { Average (Out of } \\
\text { 295) }\end{array}$ \\
\hline \multirow{7}{*}{$\begin{array}{c}\text { Average } \\
\text { experience } \\
\text { (yrs) }\end{array}$} & 0 & 5 & 2.5 & 53 & 132.5 & \multirow{7}{*}{3690.95} & \multirow{7}{*}{12.51} \\
\hline & 5.1 & 10 & 7.55 & 89 & 671.95 & & \\
\hline & 11 & 20 & 15.5 & 111 & 1720.5 & & \\
\hline & 21 & 30 & 25.5 & 35 & 892.5 & & \\
\hline & 31 & 40 & 35.5 & 6 & 213 & & \\
\hline & 41 & 50 & 45.5 & 0 & 0 & & \\
\hline & 51 & 70 & 60.5 & 1 & 60.5 & & \\
\hline \multirow{10}{*}{$\begin{array}{l}\text { Research } \\
\text { grants } \\
\text { received }\end{array}$} & 0 & 0 & 0 & 142 & 0 & \multirow{10}{*}{487050077} & \multirow{10}{*}{1651017.21} \\
\hline & 1 & 100000 & 50000.5 & 36 & 1800018 & & \\
\hline & 100001 & 500000 & 300000.5 & 45 & 13500022.5 & & \\
\hline & 500001 & 1000000 & 750000.5 & 27 & 20250013.5 & & \\
\hline & 1000001 & 3000000 & 2000000.5 & 24 & 48000012 & & \\
\hline & 3000001 & 5000000 & 4000000.5 & 9 & 36000004.5 & & \\
\hline & 5000001 & 10000000 & 7500000.5 & 7 & 52500003.5 & & \\
\hline & 10000001 & 50000000 & 30000000.5 & 3 & 90000001.5 & & \\
\hline & 50000001 & 100000000 & 75000000.5 & 1 & 75000000.5 & & \\
\hline & 100000001 & 200000000 & 150000000.5 & 1 & 150000000.5 & & \\
\hline \multirow{8}{*}{$\begin{array}{l}\text { Time spent } \\
\text { per day on } \\
\text { research } \\
\text { (min) }\end{array}$} & 0 & 0 & 0 & 13 & 0 & \multirow{8}{*}{38811} & \multirow{8}{*}{131.56} \\
\hline & 1 & 60 & 30.5 & 54 & 1647 & & \\
\hline & 61 & 120 & 90.5 & 98 & 8869 & & \\
\hline & 121 & 180 & 150.5 & 77 & 11588.5 & & \\
\hline & 181 & 300 & 240.5 & 37 & 8898.5 & & \\
\hline & 301 & 480 & 390.5 & 12 & 4686 & & \\
\hline & 481 & 720 & 600.5 & 2 & 1201 & & \\
\hline & 721 & 1200 & 960.5 & 2 & 1921 & & \\
\hline \multirow{5}{*}{$\begin{array}{l}\text { No. of } \\
\text { ongoing } \\
\text { research } \\
\text { projects }\end{array}$} & 0 & 0 & 0 & 66 & 0 & \multirow{5}{*}{699.5} & \multirow{5}{*}{2.37} \\
\hline & 1 & 3 & 2 & 177 & 354 & & \\
\hline & 4 & 5 & 4.5 & 36 & 162 & & \\
\hline & 6 & 10 & 8 & 21 & 168 & & \\
\hline & 11 & 20 & 15.5 & 1 & 15.5 & & \\
\hline
\end{tabular}

uate, post graduate, PharmD and $\mathrm{PhD}$ students guided by faculties to be $32.89,18.24,2.87$ and 3.35 respectively. In India, most of the pharmacy institutes belong to private sector and starting/running a pharmacy institute is primarily viewed as a profit making venture. ${ }^{24}$ Probably because of this scenario, $23.11 \% \quad(n=186)$ respondents in our survey have claimed that they are unable to spend time on research and this was the highest reported reason for unremarkable contribution of India in pharmacy research in the world. Majority of the pharmacy courses in India are manufacturing or lab-oriented. Aligning to this, "Laboratories should be made full-fledged" was the commonest ( $n=194,20.06 \%)$ recommendation for improvement in research by faculties. For increasing student involvement in research, "the faculties should become a role model" received the highest ( $\mathrm{n}=215,32.23 \%)$ hits in our survey.

Since 3 questions in 'opinions' category were check box type questions, we received more than 295 responses for each of them. We had asked an open ended question in the survey as "Anything else you would like to share with us?". Many responses for this were aligning to the answers for the questions in 'opinions' category and the same have been added in 'other' responses. 


\section{Limitations}

We couldn't approach every Indian pharmacy faculty or pharmacy institute. Apart from personal contacts and certain groups on Facebook, we could send the survey form only to the faculties whose email addresses were available on different websites. We couldn't approach other faculties. We tried getting more email addresses from the institute websites, but not every website contained the email addresses of the faculties. We haven't verified the survey outcomes with any official records. The calculations conducted for determination of different average values are logical and may not be directly implementable. We haven't conducted any statistical analysis of the data. As reported in the current study, more than $80 \%$ faculties in our survey had experience of more than 5 years; we couldn't approach many of junior faculties. Ahmad et al. ${ }^{14}$ have studied, the time spent by faculties on other research related activities such as meeting faculties/students, travelling, co-authoring books/book chapters etc. But we didn't solicit such questions in our survey. They have also compared the performance of faculties in private vs. public institutes, between different academic ranks and between different departments; but we haven't done so.

Kalis and Kirschenbaum study. ${ }^{25}$ has found that research/scholarship awards to faculties were formally recognized less frequently. According to the study, $38.09 \%$ faculties have received research/scholarship awards from the institution. But in our study, we haven't considered the award by the institution for recognition of research/scholarship.

The average values for many research parameters were unexpectedly higher in our research. We suspect 'more participation of senior faculties' (Average experience $=12.51$ years) and 'multiple reporting of the same publication/poster by co-authors' as the reasons behind this. Another probable reason for higher average values was wider ranges in the choices of the questions. E.g. one of the choices for number of research based publications was ' $1-10$ '. Means, if somebody has even 1 publication, he will go for ' $1-10$ ' option for which the median was '5.5' which we considered for calculating the average.

\section{Recommendations}

Many universities in western countries have 'well defined' policies for surveying their students/faculties but we couldn't find the survey policies 'defined' for any pharmacy institute in the country and we recommend the institutes to do so. AACP regularly conducts surveys for faculties and preceptors for assessing the satisfaction with the administration, performance, development and academic roles, curriculum, teaching etc. Even in our survey some have recommended that such surveys should be conducted regularly. On the similar grounds, we propose Indian associations/regulatory authorities to conduct such surveys officially and frequently. Educational research contributes for knowledge, development, practical improvement, policy making etc. It also improves competencies in teaching and learning. ${ }^{26}$ But we could find very few studies assessing Indian pharmacy faculties. Hence, further research is needed in this area to improve the overall quality.

Although we received huge 'quantitative' data through our study, 'quality' of the educational/academic research being conducted in India is not remarkable in the world. The reasons behind the poor performance of India include- dearth of scholarly faculty, less/no publications in world-class journals, lack of regular research seminars, conferences with poor academic standards, rare access to editors of major journals, poor computing and library facilities, little interaction/collaboration with industry, poor support from the government, poor stipend for researchers, draining of quality faculties from India, poor academic leadership, poor efforts to attract scholars, etc. ${ }^{27,28}$ Serious inputs are needed to solve such issues.

\section{CONCLUSION}

To the best of our knowledge, this was the first study in India assessing research productivity and involvement of pharmacy faculties in research. We have got huge 'quantitative' data from the study but that is not sufficient to improve the 'quality' in Indian pharmacy academic research. Serious inputs are required to change the scenario and to encourage the journey of research from 'lab to land'. Although the average values are not directly implementable, it may provide valued inputs for pharmacy educational research in India. Further research is indeed needed for advancements in pharmacy education system of the nation.

\section{ACKNOWLEDGEMENT}

We are thankful for the faculties who spent their valuable time for responding the survey. We are grateful for the individuals who forwarded our survey to respective faculties.

\section{CONFLICT OF INTEREST}

The authors declare that they have no conflict of interest. 


\section{REFERENCES}

1. Global pharmacy workforce and migration report. A call for action. International Pharmaceutical Federation (FIP). 2006. Available on http://fip. org/files/fip/publications/PharmacyWorkforceMigration.pdf. [Last accessed on 2017 Apr 13].

2. Approved Diploma institutions u/s 12 (Page 1-11). Pharmacy Council of India. Available on http://www.pci.nic.in/CollegesCourses/ApprovedDiploma institutionsus12.aspx. [Last accessed on 2017 Sept 26]

3. Diploma institutions only for conduct. Pharmacy Council of India. Available on http://www.pci.nic.in/CollegesCourses/Diplomainstitutionsonlyforconduct. aspx. [Last accessed on 2017 Sept 26]

4. Approved Degree institutions u/s 12 (Page 1-11). Pharmacy Council of India. Available on http://www.pci.nic.in/CollegesCourses/ApprovedDegree institutionsus12.aspx. [Last accessed on 2017 Sept 26]

5. Degree institutions only for conduct. Pharmacy Council of India. Available on http://www.pci.nic.in/CollegesCourses/Degreeinstitutionsonlyforconduct. aspx. [Last accessed on 2017 Sept 26]

6. Institutes offering Both Pharm.D. And Pharm.D. (Post Baccalaureate) Courses. Pharmacy Council of India. Available on http://www.pci.nic.in/ CollegesCourses/Baccalaureate.aspx. [Last accessed on 2017 Sept 26]

7. Institutes offering Bridge Courses. Pharmacy Council of India. Available on http://www.pci.nic.in/CollegesCourses/BridgeCourse.aspx. [Last accessed on 2017 Sept 26]

8. Institutes offering M.Pharm Courses. Pharmacy Council of India. Available on http://www.pci.nic.in/CollegesCourses/MPharmCourse.aspx. [Last accessed on 2017 Sept 26]

9. The Global Innovation Index. Analysis. View rankings by indicator (2017). Available on https://www.globalinnovationindex.org/analysis-indicator . [Last accessed on 2017 Sept 28]

10. Vinod KR, Sandhya S, Saritha A. Global Metadata Analysis of Research Publications in Pharmaceutical Sciences. Indian Journal of Pharmaceutical Education and Research. 2013;47(4):16-23.

11. Download Research Publications By Pharmacy Institutions. Pharmacy Council of India. Available on http://www.pci.nic.in/apps/Researchpublication/ Researchpubdownload.aspx. [Last accessed on 2017 Apr 13]

12. Excel Spreadsheet to Calculate Instrument Reliability Estimates. Educational Research Basics by Del Siegle. University of Connecticut. Available on http://researchbasics.education.uconn.edu/excel-spreadsheet-to-calculateinstrument-reliability-estimates/. [Last accessed on 2017 Apr 13]

13. Raosoft тм. Sample size calculator. Available on http://www.raosoft.com/ samplesize.html. [Last accessed on 2017 Apr 13]

14. Ahmad A, Khan MU, Srikanth AB, Patel I, Nagappa AN, Jamshed SQ. Evaluation of Workload and its Impact on Satisfaction among Pharmacy Academicians in Southern India. J Clin Diagn Res. 2015 Jun; 9(6):FC01-6.
15. Ahmad A, Khan MU, Ramadan ME, et al. Job satisfaction among Indian pharmacists: An exploration of affecting variables and suggestions for improvement in pharmacist role. Indian Journal of Pharmaceutical Education and Research. 2016; 50(1):9-16.

16. Durai R, Roopa BS, Ravindra J, Indu TH, Gokul G, Sivasankaran P. A study on the perspectives of pharmacy students and faculties on social networking sites. Int J Health Allied Sci 2016; 5(4):227-34.

17. Sharma A, Malhotra A, Sharma P. Responsiveness of academics to e-mails: India versus the West. Current Science. 2012; 102(1):9-10.

18. American Association of Colleges of Pharmacy Faculty Survey 2016 National Summary Report. http://www.aacp.org/resources/research/ institutionalresearch/Pages/FacultySurvey.aspx. [Last accessed on 2017 Apr 13]

19. Ahmadian S, Fakhree MA, Amini A, Jouyban A. Analysis of Pharmacy Related Publications, $\mathrm{H}$-indices, and Patents of 102 Countries. Pharmaceutical sciences, 2013; 19(2):53-8.

20. Kejariwal D, Mahawar KK. Is Your Journal Indexed in PubMed? Relevance of PubMed in Biomedical Scientific Literature Today. WebmedCentral MISCELLANEOUS 2012; 3(3):WMC003159.

21. Deshpande PR, Vantipalli $\mathrm{R}$, Chaitanya Lakshmi $\mathrm{CH}$, et al. Clinical pharmacists: The major support to Indian healthcare system in near future. J Pharm Bioallied Sci. 2015; 7(3):161-74.

22. Dotson B. Geographical composition of the editorial boards of leading pharmacy journals. Am J Pharm Educ. 2012 Oct 12; 76(8):160.

23. American Association of Colleges of Pharmacy Preceptor Survey: 2008 National Summary Report. Available on http://www.aacp.org/resources/ research/institutionalresearch/Documents/2016_Preceptor\%20Survey_ National\%20Summary\%20Report_for\%20web.pdf. [Last accessed on 2017 Apr 13]

24. Ravikumar KG, Veena R. Doctor of pharmacy education in India- strengths, weakness and opportunities. A Critical analytical study based on five year existence in India. J Horm Res Pharm. 2014; 1(3):30-47.

25. Kalis MM, Kirschenbaum HL. Faculty awards at US colleges and schools of pharmacy. Am J Pharm Educ. 2008 Aug 15; 72(4):85.

26. The Role and Importance of Educational Research Philosophy Essay. Philosophy. UKEssays. Available on https://www.ukessays.com/essays/ philosophy/the-role-and-importance-of-educational-research-philosophyessay.php. [Last accessed on 2017 Apr 13]

27. Chatterjea A, Moulick SP. Doctoral Education and Academic Research (in India). February 2006. Cornell University ILR School. Available on http://digitalcommons.ilr.cornell.edu/cgi/viewcontent.cgi?article=1066\& context=workingpapers. [Last accessed on 2017 Apr 15]

28. Global Pharma looks to India: Prospects for growth. Pharmaceuticals and Life Sciences. Available on http://www.pwc.com/gx/en/pharma-life-sciences/ pdf/global-pharma-looks-to-india-final.pdf. [Last accessed on 2017 Apr 15]

\section{SUMMARY}

- Research profile is one of the major credibility factors for an academician. Since we couldn't find any study about research involvement of pharmacy faculties in India, we aimed the same. We conducted an online survey of Indian pharmacy faculties soliciting their research involvement based on different parameters. Total 295 faculties responded to the survey. The research has generated huge data like (average values of)- research publications, conference presentations, $\mathrm{h}$ index, i10 index, total citations, time spent on research activities, number of students guided for research, patents/research grants received etc. Although huge data has been generated out of this study, such studies are rare in India. Therefore, educational research should be encouraged in the nation.

Cite this article: Deshpande PR, Chandrakar V, Bhusare K, Lalwani T, Prasanna MNL, Kanhed A, Pawar A. Research Involvement of Pharmacy Faculties in India. Indian J of Pharmaceutical Education and Research. 2018;52(1):2131. 